\title{
Formation and Development of Interest in Music in Beginner Pupils in the Process of Learning to Play the Piano
}

\author{
Zabolotnia Nina \\ Honored Worker of Culture of Ukraine \\ Piano teacher-supervisor at Revutsky Children's Arts School No. 5 in Kyiv \\ (Kyiv, Ukraine)
}

\begin{abstract}
Presented a variety of methodological techniques at the first stages of learning to play the piano in order to form and consolidate interest at the piano lessons. Purely practical approaches to solving this problem that were tested in the process of real work with children of primary school age are offered. The main idea is the need for maximum approximation of learning to play a musical instrument to the types of creative activity familiar to a child. This is the main guarantee of the most complete manifestation of the pupil's creative abilities and their subsequent development. Given specific examples that facilitate the perception of the teacher's instructions, encourage the child to work independently, meaningfully elaborate musical works, and develop a desire to communicate with music. An interesting and original know-how is music comparison with wildlife (Such a relationship contributes to the natural feeling of the phrase, the naturalness of intonation, and differentiated sound extraction). The important role of teacher's personality, his ability to creating an atmosphere of true creativity far from the mechanical fulfillment of his instructions at the lesson is emphasized. Work with pupils should be based on "child-centeredness" principle in the broadest and best sense of the word.
\end{abstract}

Key words: Piano teacher, creative activity, learning to play the piano, beginner pupils, interest.

Актуальність дослідження. У сучасних умовах, коли на дітей обвалюється шквал різноманітної, далеко не завжди корисної, а іноді просто шкідливої інформації, коли чи не в кожній родині є планшети, ноутбуки, смартфони тощо, тема виховання інтересу та любові до справжнього мистецтва стає надзвичайно актуальною. Адже зараз, на жаль, відбувається суттєва зміна ціннісних орієнтацій дітей: зростання престижу матеріальних статків, зменшення ваги моральних, етичних та інтелектуальних чинників, швидкими темпами руйнується емоційна складова як в структурі особистості, так і в суспільному бутті в цілому. Тим важливішими $є$ спроби викладачів-практиків узагальнити та розповсюдити свій досвід виховання свідомого інтересу дітей до занять музикою, зокрема в класі фортепіано.

Виклад основного матеріалу. Практично кожний із викладачів-піаністів стикався у своїй педагогічній діяльності з цікавим, але, водночас, неприємним феноменом, - коли дитина приходить до школи мистецтв із великим бажанням, біжить на уроки в піднесеному настрої, але вже через 2-3 роки ми спостерігаємо прямо протилежну картину: в’ялість, безініціативність, байдужість і навіть бажання зовсім припинити 
заняття музикою. На практиці це означає, що інтерес зберігається до тих пір, поки заняття на фортепіано сприймаються як нова іграшка, і перші ж труднощі породжують спочатку байдужість, а потім і повне несприйняття навчання гри на фортепіано, через що, питання збереження та підсилення інтересу до занять музикою залишається відкритим і потребує зосередженого аналізу та опрацювання.

Численні методики викладання гри на фортепіано, які існують на сьогоднішній день, здебільшого мають на меті виховання суто професійних якостей юних піаністів, в них суттєво бракує конкретних рекомендацій щодо розвитку та стимулювання музичних інтересів у дітей, які навчаються в мистецьких школах. Адже не є таємницею, що викладачі однаково займаються 3 усіма учнями, намагаючись систематично прищеплювати професійні піаністичні навички тим, для кого значно важливішим було би отримати більш елементарні уміння, зробити акцент на розвиток слухових та загально музичних даних, знайомстві з музичною літературою. Основною метою, яку ставить перед початковою ланкою мистецької освіти суспільство, є виховання грамотного вмотивованого слухача, достатньо освіченого аматора, людину, для якої світ музики не чужий, в якої $\epsilon$ потреба в систематичному спілкуванні 3 музичним мистецтвом [6; 7; 8;9].

На нашу думку, найбільш обгрунтованими та перспективними є твердження, які підкреслюють у даному питанні, емоційний компонент. «Мистецтво $є$ специфічною формою відтворення дійсності, а пізнання мистецтва є особливим видом пізнання, що потребує іншого, емоційного мислення...»- зазначав видатний психолог Л. Виготський [2]. Один з найвідоміших педагогів-музикантів Д. Кабалевський писав: «Ми ні на мить не повинні забувати про головне завдання: зацікавити дітей музикою, емоційно захопити їх, «заразити» своєю любов’ ю до музики [4]. Якщо хочете, це навіть не завдання, а, як говорив К. Станіславський, надзавдання всієї музично-виховної роботи 3 дітьми. Інтерес до музики, захоплення музикою, любов до неї - неодмінна умова для того, щоб вона широко розкрила й подарувала дітям свою красу».

Якщо таким чином розглядати інтерес, то стає зрозумілим, що саме емоційна складова не дає інтересу згасати, а навпаки - породжує нові інтереси, але вже на більш високому рівні. Процес музичного пізнання має бути пов’язаним з почуттям радості, здивування, захоплення, задоволення від спілкування зі світом музики. Інтерес - це 
потужна позитивна емоція, що мотивує навчання, самовдосконалення, розвиток творчих прагнень.

Зазвичай багато фахівців рекомендують проводити заняття 3 початківцями в ігровій формі. Цей прийом безперечно дає позитивний результат, але лише протягом обмеженого часу. Адже і в цьому випадку інтерес зникає досить швидко, тому що за таких умов учень частіше за все виступає в ролі пасивного споживача ігрового дійства. Заняття не обов’язково мають носити суто розважальний характер, не повинні перетворюватись на «цирк». Адже тоді, йдучи на урок, дитина настроюватиме себе на легковажну та грайливу хвилю. Завдання справжнього вчителя - якомога повніше використати вікові психологічні особливості учня, зробити його повноцінним співучасником пізнавально-творчого процесу. Дитина повинна розуміти, що справа, якою вона займається, є серйозною, потребує певних зусиль, зосередженості та наполегливості. Звичайно, такий підхід має тісно співіснувати зі створенням на уроці емоційного фону активної зацікавленості.

Узагальнення багаторічного досвіду дозволяє зробити висновок, що основне завдання викладача-піаніста - якомога більше наблизити процес занять на фортепіано до звичних для дитини вікових видів діяльності.

Перш за все, ніж приступити до вивчення прийомів гри на інструменті, учень повинен оволодіти мовою музики, полюбити ії. Основним видом діяльності маленького музиканта на самому початку навчання мають бути не спроби виконавства на фортепіано, а знайомство з музикою у широкому розумінні цього слова.

Зазначимо, що ефективно спрацьовує запропоноване вчителем уявлення про музику як про живу істоту. Особливо, якщо викладач відразу продемонструє докази того, що музика є явищем живої природи. Разом 3 дитиною неважко з'ясувати, що музика має практично усі ознаки живих істот: наявність серцебиття, дихання, зміни настрою, здатність рухатись в різних темпах і тому подібне. Потім викладач може проілюструвати ці ознаки на яскравих, показових невеличких музичних прикладах. Наприклад, чітко простежити «серцебиття» в творах танцювального характеру (варто продемонструвати це на музичному прикладі, дещо перебільшено підкреслюючи сильні долі), широке «дихання» почути в п’єсі «Бабак» Л. Бетховена, інших творах вокальної 
природи, відслідкувати співставлення мажора та мінора (тобто зміни настрою) в творах «Весело-сумно» та «До Елізи» Л. Бетховена, українських народних піснях тощо.

Треба сказати, що парадоксальне на перший погляд твердження про приналежність музики до світу живої природи довело свою ефективність та значущість не тільки для початківців. Спираючись на цю тезу, як правило, можна вибудовувати в подальшому і звуковидобування, і відчуття фрази, і роботу над динамікою твору. Коли справа доходить до безпосередньої гри на інструменті та постає питання якості звуковидобування, знову в пригоді стає відчуття музики як живої істоти. Якщо рояль вдарити прямолінійно та грубо - він «закричить», звук буде різким, неприємним. Дитина добре розуміє це твердження. Тому вона поступово звикає до акуратного, прицільного, проникливого дотику до інструменту. Звичайно, коли дитина дорослішає, вона розуміє умовність такого

підходу до музики, але звичка до дбайливого ставлення залишається.

На початковому етапі навчання дуже важливими є свідоме оволодіння клавіатурою фортепіано, вільне відчуття розташування регістрів, знання тембрального забарвлення різних октав. Надзвичайно важливим $\epsilon$ зв'язок музичної мови 3 вербальною. Дітям набагато простіше та цікавіше грати музичні приклади, які мають підтекстовку. Це значно полегшує відчуття фрази, допомагає визначити кульмінацію, зрозуміти чергування сильних і слабких долей. До речі, вводити поняття «кульмінація» доцільно з перших уроків, для початку спираючись на літературні приклади. Всі діти чудово розуміють, де є кульмінація в знайомих казках.

Одна з провідних українських викладачів-піаністів Н. Найдич [5] у своїй збірці «Будем учиться играть» весь теоретичний матеріал, адресований початківцям, виклала у віршованій формі, яку діти сприймають набагато краще, ніж звичайні прозові пояснення. Можна запропонувати учню і самому написати текст до виконуваного твору, хоча це досить непросте завдання і не всім учням під силу. Більш реальним завданням $\epsilon$ підбір назви до виконаної педагогом п`єси.

Також добре сприймаються дітьми порівняння руху музики вгору та вниз із рухом сходинками. Тут головне, щоб дитина відчувала саме рух ВГОРУ та ВНИЗ, а не праворуч та ліворуч. Вгору рухатись важче, тож людина витрачає більше енергії та зусиль, мимоволі рухається «на крещендо». Вниз - навпаки, звучання затихає, 
докладати зусиль не доводиться, сплеск енергії не потрібен. Звичайно, це - зовсім спрощене поняття про закономірності музичного розвитку, але на початковому етапі його використання можна вважати доцільним.

Додамо, що доречним є порівняння вербального речення з музичною фразою. На кінці речення ми, як правило, говоримо трішки тихіше. Це фізіологічно обумовлено. Тож і кінець фрази на інструменті здебільшого (хоча і не завжди) затихає, неначе «видихається».

Для чіткого усвідомлення поняття сильної та слабкої долі доцільно використовувати такий прийом: попросити учня вимовити будь-яке слово без наголосу. Звісно, після кількох невдалих спроб учень розуміє, що це абсолютно неможливо. Тож для дитини стає зрозумілою необхідність відчуття сильної долі як неодмінного атрибуту самого існування музики.

«Запалити, захопити дитину бажанням оволодіти музичною мовою найголовніше 3 найперших завдань педагога», - вважала видатний педагог А. Д. Артоболевська [1].

Під час знайомства з написанням нот слід пам'ятати прості, але важливі речі. Значна частина початківців вважає, що перша лінійка - верхня. Як не дивно, з цим помилковим твердженням іноді доводиться стикатися і в більш старших класах. Тут в пригоді стане порівняння нотного стану з будинком: адже поверхи ми рахуємо, починаючи з нижнього.

Під час розбору нотного тексту важливо, щоб зорове сприйняття було тісно пов’ язане з тактильними відчуттями. Потрібно, щоб учень зрозумів, що нотки, які «злиплись» на нотному стані та нагадують бантик, на клавіатурі знаходяться поруч. А ті, що вишикувались в акорді, як дитяча піраміда, одна на одній без проміжків, щільно, завжди розташовані на клавіатурі через одну клавішу. Задля полегшення читання нот 3 листа можна використовувати такий прийом: малюємо нотний стан не з 5 лінійок, а 36 або 7. Розташовуємо на ньому ноти та довільно оголошуємо назву першої ноти. Учень змушений читати цей нотний текст, виключно виходячи з графічного зображення. Тобто, на перший план виступає не назва нот, а розташування їх одна відносно іншої. Як показав досвід, цей метод добре спрацьовує, особливо в 2-3 класах. Великий ентузіазм викликає в учнів наявність «кишенькового» нотного стану, коли п’ять пальців 
на руці виконують роль п'яти лінійок, на яких пишуться ноти. Діти охоче показують розташування нот на власній долоні та пальчиках, до того ж це корисно для швидкого орієнтування в написанні нот.

Коли починається найвідповідальніший та найскладніший процес постановки рук, треба, як не парадоксально, якомога менше концентрувати увагу дитини саме на цьому процесі. Це дозволяє уникати скутості та неприродності в постановці рук, вкорінення негативних відчуттів, особливо якщо викладач має погану звичку трясти зап’ястками учня в повітрі, жорстко хапати дитину за лікті і тому подібне. В початковій постановці рук головне - свобідне почуття ваги рук, що переноситься з пальця на палець. При цьому необхідно коригувати швидкість падіння рук на клавіатуру, щоб уникнути грубого прямолінійного звуковидобування. Крім того, учень має розуміти необхідність та зручність напівзакругленої форми пальців, які повинні формувати міцний, але пружний каркас долоні.

Усім знайома вправа переносу рук по октавах. Однак вона має один суттєвий недолік: руки падають занадто швидко, звук виходить агресивним, негарним, жорстким. Хороший результат показують діти, руки яких викладач «перетворив» на сміливих парашутистів. Вони спускаються на землю повільніше, форма долоні абсолютно копіює купол парашута, та й приземляється парашутист прицільно й акуратно на ноги (пальці), стежачи, щоб ненароком їх не поламати.

Надзвичайно важливими складовими, що сприяють підтриманню інтересу до занять $є$ максимальне розширення репертуару, якомога більша кількість задіяних в роботі творів, гра в ансамблі, читання незнайомих творів $з$ листа.

Не варто вимагати від учня досконалого виконання всіх творів, які є в його репертуарі. Важливо прищепити дитині прагнення познайомитись 3 якомога більшою кількістю різноманітних п’єс. Адже важко уявити собі, яким би був інтерес учня до уроку рідної мови, якби протягом семестру дитина вивчила б тільки 2-3 вірші або прочитала 1 або 2 оповідання!

У великій пригоді стає ансамблеве музикування. Проста та невибаглива мелодія, виконувана початківцем, звучить виразно і яскраво в супроводі гармоній партії secondo. Можна змінювати фактуру викладення другої партії, щоб учень зрозумів сутність та можливості різних видів музичної фактури. Важливо на першому етапі навчання значну 
частину дитячих пісеньок виконувати в ансамблі з педагогом. Користь від такого музикування, навіть суто психологічну, важко переоцінити. Адже творчим партнером дитини в даній ситуації виступає сам учитель, авторитет якого на початковому етапі навчання сумніву не підлягає. Розумний педагог зможе зробити так, що учень відчує себе артистом, рівним шанованому та любимому вчителю!

Не менш корисним є підбір на слух мелодій, які є в репертуарі учня або знайомі дитині з телепередач чи просто з життєвого досвіду. Зокрема можна практикувати гру уривків з таких відомих українських народних пісень, як «Їхав козак за Дунай», «Дівка в сінях стояла», «Ой лопнув обруч», «Перстень» та ін. від усіх білих та чорних клавіш. Це привчає дитину не боятись гри на чорних клавішах. А розпочинати процес підбору на слух можна з аналізу простих мелодій (або їх фрагментів), знаходячи повторювані звуки, визначаючи ритмічний малюнок; допомагає аналіз інтервального складу мелодій (звичайно, в спрощеному вигляді), розуміння напрямку руху в пісеньці. Підбір на слух також породжує, а надалі й розвиває, відчуття тоніки. Така складова музичного виховання і досі залишається поза увагою значної частини викладачів. Хоча, йдучи навчатись музиці, дитина підсвідомо мріє навчитись грати знайомі твори без нотного тексту.

Питання репертуару - одне з найважливіших протягом усього періоду навчання. Від вдало підібраних для опрацювання творів багато в чому залежить ставлення учня до занять фортепіано в цілому. Чимало викладачів, яких не повністю влаштовують існуючі репертуарні збірки, вдаються до створення власних.

На наш погляд, привертає увагу серія «Забуті імена», що створена на факультеті мистецтв НПУ імені М. П. Драгоманова. До першої збірки серії увійшли легкі твори прекрасних українських композиторів В. Барвінського, С. Шевченка, М. Любарського, І. Віленського, П. Козицького, М. Скорульського.

Опора на національний репертуар дає завжди позитивний результат, тому що сприймається дитиною на глибинному, генетичному рівні.

Враховуючи психологічні особливості 6-7 річних дітей (вразливість, підвищену сприйнятливість, предметне мислення), корисно, по можливості, залучати до репертуару побільше творів з цікавими назвами. Наприклад, в навчальному посібнику для малят «Хочу грати на роялі» відомий український педагог Наталія Гриднєва [3] 
використовує твори та вправи з такими назвами: «По сходинках», «Веселі півтони», «Равлик», «Обережні кроки», «Зламана машина» та багато інших. Взагалі, на уроці має панувати атмосфера творчості в прямому смислі цього слова. Учень не повинен відчувати, що викладач вже десятки разів опрацьовував твори 3 іншими дітьми. Навпаки, вчитель має дивуватися разом з учнем, почувши цікаве співзвуччя, радіти кожному виразному мелодійному звороту. Кожен вчитель має бути трішки актором. Він ні в якому разі не може бути просто джерелом інформації для дитини - а повинен стати другом і навіть в якомусь розумінні колегою для маленького музиканта. Має щиро радіти найменшим успіхам дитини, заохочувати іiі до подальшого розвитку та вдосконалення, вчитись разом з нею.

Дуже корисною є гра, пов'язана зі зміною ролей - викладач та учень міняються місцями. Викладач навмисне виконує твір незграбно, 3 помилками, 3 алогічною динамікою. Завдання учня - почути недоречності та помилки, по можливості скоригувати їх. Ця ігрова модель надзвичайно активізує увагу дитини, підвищує іiі впевненість в своїх силах. Інший варіант, коли учень оцінює гру іншого учня та дає йому поради щодо покращення виконання твору. Цей варіант придатний для більш старших учнів.

Надзвичайно важливо виховати в учнів повагу та пієтет до виконуваних творів, привчати саме виконувати їх, а не просто програвати. Необхідно, щоб дитина розуміла, що вона має передати саму сутність твору, навіть найпростішого, заразити слухачів своїм інтересом до виконуваної п“єси, передати їм щире захоплення нею. 3 перших кроків маленький музикант повинен відчувати себе артистом, а не слухняним та безсловесним відтворювачем чиїхось настанов. Тоді він вчитиметься 3 більшим бажанням та натхненням.

Висновки. Отже, скільки учнів - стільки різних прийомів доводиться шукати викладачу, аби музика стала невід’ємною частиною життя дитини.

Подолання заакадемізованості навчального процесу, наближення навчання до природних видів діяльності дитини дозволить сформувати в неї позитивне ставлення до занять музикою. Своєю чергою, розумний і небайдужий викладач знайде необхідні методичні прийоми, здатні зберегти та примножити інтерес учня до навчання гри на фортепіано. Головне - відкинути зайві педагогічні амбіції, не займатися з дитиною 
безглуздим та безпредметним вишколом, а дотримуватись «дитиноцентризму» в найкращому та найширшому сенсі цього слова. Музика повинна зайняти в житті дитини важливу «нішу», яка нічим іншим бути зайнята просто не може.

\section{References}

1. Artobolevskaya A. D. The first meeting with music. Moscow: "Soviet composer", 1985. $101 \mathrm{p}$.

2. Vygotsky L. S. Questions of child psychology. Collection of works V. 4 T. Moscow: Pedagogy, 1984. $432 \mathrm{p}$.

3. Gridneva N. V. I want to play the piano. Kyiv: "Musical Ukraine", 2012.193 p. 319 p.

4. Kabalevsky D. B. How to tell children about music? Kyiv: "Musical Ukraine", 1981.

5. Naydich N. M. Let's learn to play. Kyiv: Optima, 2010. 48 p.

6. Pet ko L. V. Lingvosociokulturnyj pidhid u vyvchenni anglomovnoyi novorichnoyi pisni «Jingle Bells» [Lingvosociocultural Approach to Teaching American New Year's Song «Jingle Bells»] // Topical issues of redagogy : Collective monograph. - Edizioni Magi, Roma, Italy, 2019. P. 31-57.

7. Pet'ko L. V. Shljahy formuvannja inshomovnoi' sociokul'turnoi' kompetencii' studentiv mystec'kyh special'nostej VNZ u procesi fahovoi' pidgotovky [The Ways of Formation of Foreign Language Socio-Cultural Competence of Students of Music-Pedagogical Specialties in Higher School in the Process of Professional Teaching]. Problemy pidgotovky suchasnogo vchytelja. 2012. Vol. 6. Part 3. Pp. 57-62.

8. Shcholokova Olga, Ding Yun. Pedagogical Principles of Young Pupils' Music Culture Formation in Piano Teaching Process. Intellectual Archive. 2015. Volume 4. No. 6 (November). Toronto : Shiny Word Corp., 2015. Pp. 160-169.

9. Zhang Jiangan. The methods on forming the worldview culture of future Music teachers in the process of piano learning. Intellectual Archive. Toronto: Shiny Word.Corp. (Canada). 2020. Vol. 9 (April/June). No. 2. Pp. 151-162.

DOI: https://doi.org/10.32370/IA_2020_06_18

Translation of the Title, Abstract and References to the Author's Language

\section{УДК 373.5.091.3:780.616.432}

Заболотня Н. М. Формування та розвиток інтересу до занять музикою в учнів-початківців у процесі навчання гри на фортепіано.

Розглянуто питання необхідності застосування різноманітних методичних прийомів на перших етапах навчання гри на фортепіано 3 метою формування та закріплення інтересу до занять. Пропонуються суто практичні підходи до вирішення цієї проблеми, які були опробувані у процесі реальної роботи з дітьми молодшого шкільного віку. Основною тезою є необхідність максимального наближення навчання гри на 
музичному інструменті до звичних дитині видів творчої діяльності, що головною запорукою якнайповнішого прояву творчих здібностей учня та їх подальшого розвитку. Також наведено конкретні приклади, які полегшують сприйняття вказівок педагога, спонукають дитину до самостійної роботи, осмисленого опрацювання музичних творів, розвивають бажання спілкуватися 3 музикою. Цікавим та оригінальним ноу- хау $є$ співставлення музики з явищами живої природи. Такий зв'язок сприяє природному відчуттю фрази, інтонації, диференційованому звуковидобуванню. Акцентується важлива роль особистості педагога, його вміння створити на уроці атмосферу справжньої творчості, далекої від механічного виконання його настанов. Робота 3 учнями має будуватись за принципом «дитиноцентризму» в найширшому та найкращому сенсі цього слова.

Ключові слова: учитель по класу фортепіано, креативність, навчання гри на фортепіано, учні-початківці, інтерес.

1. Арторература
А. Д. Первая встреча с музыкой. Москва : «Советский композитор», $1985.101 \mathrm{c}$.

2. Выготский Л. С. Вопросы детской психологии. Собрание сочиненй в 4 т. Москва : Педагогика, 1984. 432 с.

3. Гриднєва Н. В. Хочу грати на роялі. Київ : «Музична Україна», 2012. 193 с.

4. Кабалевський Д. Б. Як розповідати дітям про музику?. Київ : «Музична Україна», $1981.319 \mathrm{c}$.

5. Найдич Н. М. Будем учиться играть. Київ : «Оптіма», 2010. 48 с.

6. Петько Л. В. Лінгвосоціокультурний підхід у вивченні англомовної новорічної пісні «Jingle Bells» // Topical issues of redagogy : Collective monograph. - Edizioni Magi, Roma, Italy, 2019. P. 31-57.

7. Петько Л.В. Шляхи формування іншомовної соціокультурної компетенції студентів мистецьких спеціальностей ВНЗ у процесі фахової підготовки. Проблеми підготовки сучасного вчителя: зб. наук. пр. Уманського держ. пед. ун-ту імені Павла Тичини. Умань : ПП Жовтий О.О., 2012. Випуск 6. Ч. 3. С. 57-62.

8. Shcholokova Olga, Ding Yun. Pedagogical Principles of Young Pupils' Music Culture Formation in Piano Teaching Process. Intellectual Archive. 2015. Volume 4. No. 6 (November). Toronto: Shiny Word Corp., 2015. Pp. 160-169.

9. Zhang Jiangan. The methods on forming the worldview culture of future Music teachers in the process of piano learning. Intellectual Archive. Toronto: Shiny Word.Corp. (Canada). 2020. Vol. 9 (April/June). No. 2. Pp. 151-162.

DOI: https://doi.org/10.32370/IA_2020_06_18 